Research Report No. 17/2007

\title{
New-ish Governance and the Legitimacy of the EU
}

Colin Scott

Follow this and additional works at: http://digitalcommons.osgoode.yorku.ca/clpe

\section{Recommended Citation}

Scott, Colin, "New-ish Governance and the Legitimacy of the EU" (2007). Comparative Research in Law \& Political Economy. Research Paper No. 17/2007.

http://digitalcommons.osgoode.yorku.ca/clpe/234 


\section{Comparative Research in Law \& Political Economy}

\section{Colin Scott}

New-ish Governance and the Legitimacy of the EU

Paper for presentation at the Irish European Law Forum, January 2007

EDITORS: Peer Zumbansen (Osgoode Hall Law School, Toronto, Director, Comparative Research in Law and Political Economy, York University), J ohn W. Cioffi (University of California at Riverside), Lindsay Krauss (Osgoode Hall Law School, Toronto, Production Editor) 

CLPE Research Paper 17/2007

Vol. 03 No. 05 (2007)

\title{
Special Symposium Issue: EU Governance
}

\author{
PROCEEDINGS FROM THE $10^{\mathrm{TH}}$ IRISH EU LAW FORUM, UNIVERSITY COLLEGE \\ DUBLIN, 19 JANUARY 2007
}

\section{Colin Scott}

\section{NEW-ISH GOVERNANCE AND THE LEGITIMACY OF THE EU}

\begin{abstract}
The way the EU is governed and the way such governance is perceived contributes centrally to the legitimacy of the European enterprise. This legitimacy underpins both the acceptance and the effects of EU activity. Legitimacy is a product of the way in which decisions are taken and the nature of quality of such decisions. Pressures created by concerns about both forms of legitimacy affecting EU decision making partially explain the turn in legal scholarship away from the more traditional preoccupation with the analysis of legislative instruments and case law towards a more broadly based conception of governance which involves the examination of a more diverse range of processes and instruments. This paper offers an analysis of the parameters of newness in governance. The overall argument is that some of the more innovative governance modes are not so new, whilst more recent and celebrated modes, although displaying elements of newness are, perhaps, not that innovative. Hence the suggestion that we are experiencing only 'new-ish governance'. The paper asks whether a limited conception of new governance is inevitable given the legitimacy constraints within which the EU operates, or is their potential for developing a broader conception of governance, which through broader participation and involvement of non-governmental governing capacities, might bolster legitimacy through both better processes and better outcomes.
\end{abstract}

Keywords: EU governance, legitimacy, modes of governance

JEL classification: K33

Author Contact: Colin Scott

University College Dublin School of Law

Roebuck Castle, Belfield, Dublin 4, Ireland

Email: colin.scott@ucd.ie 


\title{
NEW-ISH GOVERNANCE AND THE LEGITIMACY OF THE EU
}

\author{
Colin Scott ${ }^{*}$
}

\section{INTRODUCTION}

The governance of the European Union is a central preoccupation of policy makers at both EU and national level, and observers both amongst citizens (often represented by the media) and academics. The way the EU is governed and the way such governance is perceived contributes centrally to the legitimacy of the European enterprise and this legitimacy underpins both the acceptance and the effects of EU activity. Legitimacy is, to varying degrees in different contexts, a product of the way in which decisions are taken and the nature of quality of such decisions. In this paper I adopt a simple working definition of legitimate decisions as ones which are accepted and followed by those to whom they apply, irrespective of whether those subject to them agree with them. In some contexts the process is everything in achieving legitimacy defined in this way, whilst in others no one cares about the process provided the outcome is judged to be correct. Most decision contexts are likely to involve a legitimacy evaluation which involves a mixture of the two.

Pressures raised by concerns about both forms of legitimacy affecting EU decision making partially explain the turn in legal scholarship away from the more traditional preoccupation with the analysis of legislative instruments and case law towards a more broadly based conception of governance which involves the examination of a more diverse range of processes and instruments. This trend has brought lawyers increasingly into contact with other disciplines, notably political science, an interdisciplinary pact well represented in the five year programme of research funded by the European Commission's Framework Six Research Programme under the rubric of 'New Governance'.

* Colin Scott is the Vice-Principal for Research and Innovation, UCD College of Business and Law and the Professor of EU Regulation and Governance, UCD School of Law. 
This paper sets the scene for the analysis of EU governance across the regulation of markets and social Europe by contrasting a more traditional conception of EU law with an analysis of variety in the forms of 'new governance' instrument. I offer an analytical introduction to some of the issues of governance facing the European Union, and to offer an argument relating to the choices that have been made in both defining, from a public policy perspective, changes in the modes of governance to be adopted, and understanding, from an academic perspective, the nature of the choices made, the reasons for such choices and the opportunities that may have been missed.

An analysis of the parameters of newness in governance is offered as the basis for an evaluation of recent initiatives and discussion. The overall argument is that some of the more innovative governance modes are not so new, whilst the more recent and celebrated modes, while displaying elements of newness are, perhaps, not that innovative. Hence the suggestion that we are experiencing only 'new-ish governance'. The question I ask in the paper is whether this limited conception of new governance is inevitable given the legitimacy constraints within which the EU operates, or is there potential for developing a broader conception of governance, which, through broader participation and involvement of nongovernmental governing capacities, might bolster legitimacy through both better processes and better outcomes.

\section{GOVERNANCE AND THE EU}

The emergence of European Community Law as a field of practice and academic study over the last fifty years has been an uneven one. Much of the early organising analysis was carried out by public international lawyers who were accustomed to thinking about international organisations in terms of their legal mandates and legal instruments. The view of the European Community law as an aggregate of intergovernmental organisations could not survive the assault on more conventional doctrines as to the effects of international law which were initiated by the European Court of Justice in the 1960s and 1970s, and a

different view of EC law as something which was neither national law nor 
international law but rather a sui generis legal system became the new orthodoxy.

The focus of analysis within this sui generis conception of EC law lay with the legal status, capacities and processes of the institutions, together with the nature and effects of legal instruments as they were interpreted, in particular, by the Court of Justice. The particular emphasis of the teleological reasoning of the court has been on a process of European integration through law. This way of thinking, rooted in the understanding of the potential of, and limits to Community law, enabled the European Commission in its White Paper on Governance (2001) to describe the classic 'community method' of governance. The Community method is conceived in terms that exclusive responsibility for making policy and legislative proposals lies with the Commission, such proposals are filtered through the more democratic institutions of the Parliament and the Council of Ministers through processes for adoption, implementation is carried out by the Commission and by Member States, and the Court of Justice guarantees respect of the rule of law (European Commission 2001: 8). This description captures the whole policy cycle for those actions which are pursued through the adoption and implementation of regulations and directives, though of course fails to hint at the complex processes of bargaining and negotiation at each stage.

We can think of the Community method as involving the setting of legal rules by the legislative institutions, at the initiation of the Commission, the monitoring by the Commission of member state implementation, with the potential administrative and judicial infringement proceedings where implementation falls short of requirements - a process driven by legal rules and processes. The Community method may be defined in terms of core values (notably the pursuit of a common market), core tools (and in particular the elaboration of deployment of instruments of Community law) and core actors (of which the Community institutions, the Council of Ministers, the Parliament and the Commission, are the central actors, but key roles are assigned also the Court of Justice and Member State governments). 
An exclusive focus on the Community method has become untenable because so much activity which is clearly relevant to the governance of the EU is pursued through other processes and instruments. Lawyers and others have similarly questioned an overly narrowly focus on governance by law in domestic legal systems. The analysis of political scientists and sociologists has been particularly influential in promoting a broader view of governance, to which I turn in the next section. Within this kind of analysis governance has come to be reconceptualised as involving a wider array of mechanisms and actors which steer social and economic behaviour. Policy makers and academics have, to some extent, embraced this broader conception of governance and, in the EU context, labelled it 'the new governance'.

\section{NEW GOVERNANCE}

So, the focus by legal scholars on the classic Community method has, in recent years, fallen victim to a dissatisfaction that in terms of understanding European governance, key parts of the picture are missing, and that the development of a broader conceptualisation offers new opportunities for better governance (in at least two senses, wider participation and more effective instruments) and richer and more interdisciplinary understandings of what is happening in particular policy domains. Most straightforwardly, practitioners and academics working in particular domains readily observed that key aspects of the governance of their particular domains diverged, often markedly, from the classic community method. Examples can be identified in respect of environmental and consumer protection, competition policy, employment policy and so on. At a macro-level both policy and academic communities abstracted from this domain-specific experiences to reconceptualise not only the instruments, but also the relevant actors, and to some extent the values to be pursued, as standing in opposition to or at least as a development from and shift in emphasis from, the classic 'Community method'. Hence the 'new governance.' 
In the policy world a key part of this process was the articulation of the 'Lisbon agenda' by the Heads of Government meeting in 2000. The core objective of Lisbon was defined as making Europe "the most competitive and dynamic knowledge-based economy in the world, capable of sustainable economic growth with more and better jobs and greater social cohesion". In terms of governance the core innovation identified with Lisbon is the aggregation of a variety of mechanisms which deviate markedly from the Community method of policy making, under the rubric of the 'open method of coordination' (OMC). As expressed by the Portuguese Presidency of the EU in 2000, OMC provided a marked contrast with the Community method. The norms or goals of a policy domain, rather than being set through legal rules, appear in the form of guidelines set at inter-governmental level, but to be implemented in national policies and targets (Hodson and Maher 2004). Monitoring involves an evaluation against qualitative and quantitative indicators and benchmarks. Enforcement deviates markedly from the legal or hierarchical model, and is based instead on evaluation, peer review and mutual learning. It is the antithesis of harmonisation through law. The European Employment Strategy provides a core example of the approach (Kilpatrick 2006).

For many, in both policy and academic worlds OMC is the archetypal form of the 'new governance', notably in the European Commission funded programme of research on new governance (Burca and Scott 2006: 3) The concept of OMC is simultaneously an organising narrative but also a "legitimising discourse" for the governance processes implicated in delivering on the Lisbon Agenda, and in particular those instruments involving soft law and benchmarking processes at their core (Radaelli 2003).

However, the 'governance turn' is not exhaustively covered by the Lisbon agenda and research on the operation of the Open Method of Coordination. Indeed, the concept of governance deployed in the social sciences more generally draws our attention to a wider set of issues concerning who governs, how they govern and in pursuit of what values or objectives they govern. 
Whilst there is no consensus on what the concept of governance connotes, it is frequently deployed to highlight the destabilisation of traditional government-centred governance, and the diffusion of governing capacity and legitimacy to a wider array of actors. This has important implications for instruments, since the legal and coercive instruments which define the nature of governmental power are not generally available even to governmental actors other than in central government, let alone in the nongovernmental sphere (Kersbergen and Waarden 2004). On the other hand there are things that non-governmental actors can do that may not be possible, or if possible then may not be legitimate for governmental actors. These changes, which partly involve real transformation in underlying governing institutions and processes, and partly a reconceptualisation of how governance occurs, impact both on both the procedural and substantive dimensions of legitimacy, calling into question an exclusive focus on governance institutions legitimated by mechanisms of democracy, while at the same time highlighting positive dimensions of the effectiveness of non-state governance capacity (Black 2001).

Processes of private and self -regulation provide examples of the sort of structures involved. Where bilateral coordination between firms fails, the governing norms for technical production and increasingly managerial processes are largely set through private standard-setting organisations (sometimes with government funding) at national and supranational level (Schepel 2005)). Much social regulation is achieved through association of businesses, often motivated by a concern to protect the market reputation of their members, but in a manner which can deliver on public interest objectives, with or without some governmental monitoring and or steering. The European Advertising Standards Alliance has amongst its member 25 self-regulatory organisations from 25 member states (http://www.easaalliance.org/).

What is striking about private standards processes and advertising selfregulation in Europe is that neither is particularly new. The leading standardisation institutes, DIN, AFNOR and the BSI were established in the first quarter of the twentieth century (Hallström 2004). The UK Advertising Standards Authority, which provides a model for a number of EASA members was established in 1962 in response to the damage to the credibility of the advertising industry associated with Vance Packard's 
pioneering book, The Hidden Persuaders (1957) (Baggott and Harrison 1986).

Maybe the newness in 'new governance' refers to the use of different (though well-established) mechanisms of governance in the new context of European governance. In her work on regulatory innovation, Julia Black suggests that innovation might well involve 'the application of new solutions to old problems, or new solutions to new (or newly constructed) problems, but not old solutions to old problems' (Black 2005: 9). Furthermore she helpfully distinguishes three levels of change in a regulatory regime: change in the settings, for example the level of emissions permitted in a pollution control regime; at the second level a change in the instruments or institutions of regulation, for example the introduction of tradable permits to replace prohibitions on emissions or the deployment of enforced self-regulation; and at the third level, change in goals or objectives of the regime, a paradigm shift, in which the rationales for, and cognitive understanding of the regime is changed, as when pollution control shifts from tackling the immediate problems of damage to the local environment, to tackle climate change.

Level one is not innovation, Black suggests, but a change in the settings only. From an innovation perspective levels two and three are of more interest. Level two has at least two dimensions, changes in institutions and changes in instruments. Level three is concerned with the re-programming of policy in a domain with new goals and objectives, and even a new way of seeing the domain and the purposes of policy with it.

Applying these insights to the puzzles of EU governance, and addressing level three first, the values associated with the Community method focus largely on European integration and the completion of the Single Market. For both the legislative institutions and the courts integration has been a sort of meta-value below which we find other policy objectives such as the more obvious free trade and competition, and the less obvious employment and consumer policies which were at their origination directed, to a greater or lesser extent, also to the Single Market objective through promoting employment mobility and confidence in cross-border consumer purchasing respectively. 
An important question, therefore, is to what extent 'new governance' involves a shift away from the traditional preoccupation with the completion of the single market. This involves an evaluation of the extent to which Treaty changes and policy developments have separated, in particular, social policies, from the European integration ideal, and made them freestanding. An index for the extent to which such a separation has occurred may be gained by an evaluation of the extent to which measures in such areas as employment, consumer protection and environmental protection extend beyond that which could be justified by reference to the integration objective. Such an evaluation is beyond the scope of this paper and has generally not received much attention in the new governance literature. However, this theme is reflected in the structure of this European Law Forum, bringing together as it does expertise both in the liberalisation of markets and the development of policy initiatives sometimes labelled with the rubric of 'social europe'.

Second level change - change in instruments and institutions - has received the most attention in discussion of new governance. Starting with instruments, new governance mechanisms frequently deviate from the 'rule by law' model which is closely associated with classic EC programmes. What other instruments are available? One way to approach the question is by reference to the resources or 'tools of government', available for implementing policy. A classic analysis of government capacities points to formal authority (or as Weber had it, the monopoly of legitimate force) as one of a number of relevant tools. Formal authority underpins the capacity to act through the use of law, as with the Community method, with its emphasis on directing member state governments, undertakings and citizens and backing up such directions with legal monitoring and enforcement capacity.

Other tools include Treasure, Nodality and Organisation. A helpful acronym to remember the set is NATO (Hood 1984: 4-7). The concept of Treasure attempts to capture the capacity of governmental actors to steer behaviour through expenditure decisions, for example by offering subsidies or writing conditions into purchasing contracts. The concept of nodality alerts us to the position of governments at the centre of elaborate networks of exchange of information and perspectives on the policy world, which can be harnessed to shape the way that other actors think about what is possible and or desirable. The idea of organisation is concerned 
with the capacity of governments to use their substantial staffing and organisational resources to achieve government objectives.

Set within an examination of the tools of government, what is striking about 'new governance' is the extent to which its mechanisms are based on the resource of nodality. Thus OMC exploits the governmental capacity of the Council of Ministers linked to nodality to offer an alternative to steering member state behaviour through law. Bench-marking and peer review invite governments to identify best practice and converge on it, but as a voluntary matter. Other mechanisms which deviate from the rule by law model of governance are similarly very largely based on the exploitation of nodality. For example, the building of networks of regulators in the fields of energy, telecommunications, competition and financial services, whether with or without legislative underpinning, enables the Commission to steer the behaviour of regulators through the development of epistemic communities where loyalty, core values and methods can be developed amongst the group. Equally the main emphasis of the activities of the new European agencies lies in collecting and using information in relationships with member state governments and the European Commission. A final example involves the development, by the Commission, in particular, of soft law instruments' such as guidance, letters of comfort, and circulars, which draw on the authoritative position of the Commission (or sometimes the Council) at the centre of nodes of EU governance, but without the direct deployment of legal authority (where legal authority frequently requires the involvement of other legislative institutions who may or may not be willing to comply with Commission policies). Soft law instruments are defined as instruments which are not legally binding which may have (and indeed are intended to have) practical effects (Snyder 1993).

It is striking that the European institutions make remarkably little use of the other tools of government - Organisation and Treasure. This is, of course readily explicable. In terms of organisation the European institutions are tiny. The most recent statistical bulletin (January 2007) reveals that the Commission, which is the largest institution and the main focus of institutional capacity, has fewer than 23,000 employees on its payroll. Compare this with the (diminishing) number of staff employed in the British civil service (over half a million of the 5M-plus public sector employees (2006, Q3)) and the (increasing) numbers of civil servants in 
Ireland $(38,400$ out of a total public sector employment base of over 350,000 (June 2006). EU legislative policy does, of course, use the organisational capacity of member state governments extensively, but at one remove from the EU institutions themselves, and this is regarded as an integral part of the Community method, rather than something new.

Turning to the limited capacity for the use of treasure, the total EU budget for 2006 of 112 B Euro may not appear small, but it is only just over one per cent of the GNP of the Union and thus, compared to national government budgets, is tiny. Areas of major expenditure in support of policy, such as agricultural subsidies (nearly half the entire budget) and the structural funds are very much the exception. The budget for the entire field of competition policy for 2006 was only 69M Euro. Even in an area of policy like humanitarian aid, in which the chief instrument is treasure, the budget for 2006 amounted to less than .75B Euro.

The second aspect of these level two innovations is institutional change. A central feature of the wider discussion of governance has been a perception that central government actors have been displaced by actors in other parts of government and by non-governmental actors - a process of fragmentation (Scott 2004). To what extent has institutional change been part of the 'new governance' reforms in the European Union? One response is to say that the EU institutions themselves are a central part of the fragmentation of the governing capacity of governments. There is certainly considerable truth in this. The judicial interpretation of the Treaty of Rome, in particular, made clear if not the exact extent then certainly the issue of the extent to which legal supremacy was ceded from member state legislatures to the EC legislature in its areas of competence.

But this observation about the fragmentation of legal capacity does not take away from the claim that the Community method, in our terms, is old governance. What institutional changes contribute to the new governance? Some commentators advocate the deployment of new European agencies as a radical departure from Commission-led governance towards more independent and technocratic non-majoritarian institutions (Majone 2001). But while there have been a number of waves of new European agencies, as noted above, they have generally not conformed to Majone's ideal of the powerful and independent regulator. Rather they are satellite organisations to the Commission and, set against the frequent claim that 
they are instruments of decentralisation (Geradin and Petit 2003), their effect in many domains, such as environment and food safety, appears to be to consolidate the centralised power of the Commission (Scott 2005).

The ideal-typical instances of OMC involve little institutional innovation and little by way of involvement of new actors. The European Employment Strategy does, of course, involve dialogue with the 'social partners', employers and unions, and, prior to this the social partners had been given special standing in respect of processes for both making and implementing EC employment legislation (EC Treaty Arts 137-9) (Kilpatrick 2006). But the emphasis of the OMC processes, more generally, is in benchmarking and peer review between the governments of member states, coordinated through the Council.

To find institutional innovations which draw in a wider range of actors we need to look elsewhere. Mention has already been made of processes for standard setting which are the responsibility of non-state standardisation organisations. In the 1980s the Commission and the EC legislature took steps to incorporate such standards more directly into European governance through the development of the 'new approach to technical standards' which aimed to set a minimum standard through legislation and encourage voluntary take up of more stringent non-legislative standards. Whilst for many new governance watchers the 'new approach' is recognised as an early form of deviation from the Community method (Burca and Scott 2006) the extent to which it departs from old governance models is understated. The 'new approach' is a more or less complete delegation of the capacity to make rules to non-governmental bodies, except to the extent that the power is retained by the legislature (Schepel 2005).

A similar approach can be seen in the area of consumer product safety, where the 1992 Directive (92/59/EC, repealed and replaced by 2001/95/EC) created a hierarchy of standards, such that producers of consumer goods could demonstrate compliance with the general safety requirement through compliance with non-state standards, in the absence of a specific legislative standard (Hodges 2005). 
Turning from standard setting to enforcement, another earlier form of diffused governance is found in the Directive on Unfair Terms in Consumer Contracts (93/13/EEC) which requires member states to empower consumer organisations to enforce compliance with the rules prohibiting the use of unfair terms in consumer contracts. This enforcement power is capable of being used to negotiate the reformulation of contract terms between consumer groups and businesses even in the absence of any consumer having suffered loss as the result of the inclusion of an unfair term.

In both the standards and the unfair terms cases the governmental resource of authority is deployed effectively to delegate standard-setting (standards) or enforcement (unfair terms) capacity.

Also in the consumer field, we find that the 1984 Directive on the Control of Misleading Advertisements (84/450/EEC, amended by Directive 97/55/EC and to be replaced by the Unfair Commercial Practices Directive 2005/29/EC) empowers member states to rely on self-regulatory regimes as the first port of call for enforcement of the requirements of the directive (which relate to the likelihood of economic loss caused by misleading advertisements rather than misleandingness per se), thus giving considerable encouragement to the development of self-regulatory organisations in this domain, as discussed above. A more general permission for member states to place dependence on self-regulatory codes is contained in the Unfair Commercial Practices Directive (2005/29/EC, art 10). Such self-regulatory regimes are significant for the extent to which they move the governance model away from governmental legal authority for rule making and enforcement, towards an alternative which is based on voluntary membership of self-regulatory associations linked to contractual rule making, monitoring and enforcement powers.

The deployment of the 'new governance' might be expected to involve all three forms of innovation when compared with the classic model - the shift in values and goals, the use of instruments and mechanisms other than law and greater involvement of non-governmental actors. In practice most of what passes for new governance involves a deviation from classic models in only one of these parameters, that is the use of non-legal instruments. The key example of the various forms of Open Method of 
Coordination is concerned with coordination of national governments using the resource of nodality.

We find rather little evidence of a shift towards greater involvement of non-governmental actors in governing. There is, of course, a recognition of non-state actors within policy networks but this is far from new. In any case, new governance in this dimension would surely involve not just policy discussion but also involvement in the operational tasks of governing. The examples discussed above, standardisation, consumer enforcement and advertising self-regulation have elements of this regulatory diffusion, but these measures pre-date Lisbon and could hardly be described as new. Thus, this highly incomplete survey suggests that there may not be that much EU governance that is new in both the instruments and institutions dimensions, and what there is, in many cases, only new-ish. What passes for new, in the sense of post-Lisbon, is perhaps less innovative than some earlier initiatives. As to the third level of innovation, the re-programming of policy domains with different values, I leave it to others here to debate the extent to which the emphasis on 'social Europe' is subsidiary to more traditional concerns with market integration, or alternatively a radical change in direction for the EU. I will proceed now to consider some of the implications for legitimacy arising from the new and new-ish governance.

\section{LEGITIMACY}

To the extent that changes have occurred in governance, whether in core values and goals, instruments and mechanisms, and institutions and actors such changes are likely to disrupt the way in which the legitimacy of the EU governance is understood. As noted in the introduction, in this paper I am working with a simple conception of legitimate decisions as those which command support and are followed by those affected by them, irrespective of whether those affected agree with them. Domestic government decision making derives a substantial part of its legitimacy from processes of democratic governance which include regular elections, parliamentary scrutiny, rule by law and accountability to the courts. Such a legitimacy narrative places considerable emphasis on the processes. 
An equivalent narrative for the EU has always been somewhat problematic.

There has long been a tension between a legitimating narrative which emphasises the inter-governmental and directly elected elements of the EU legislature, on the one hand, and the technocratic mission of the European Commission on the other. Some see appropriate systems of balances and checks between these two dimensions of the EU institutions, whereas for others there is a constant risk the technocratic and undemocratic dimension will trump the more democratic aspects of the institutional balancing act. This debate is a version of the classic legitimacy debate which pits the need for efficient and effective governmental decision making against the need to demonstrate accountability for decisions to democratic processes. As with much domestic debate, the European debate is infected too with questions about the capacity for institutions to serve their own interests rather than those of the European populace.

The debate about the balance between democratic and technocratic decision making reflects the distinction between input-oriented and output oriented legitimacy (Scharpf 2001). 'Input-oriented legitimacy' refers to the sense that processes through which decisions are made are appropriate, irrespective of the actual outcome. 'Output-oriented legitimacy' refers to the acceptance of decisions premised upon their substantive quality, rather than the process through which they are made. The 'Community method' combines both forms of legitimacy, looking to the role of the Commission as initiator of policy and legislation to develop knowledge and expertise, whilst filtering its proposed actions through processes involving both inter-governmental and directly elected representation in the Council and the Parliament. Much legislative activity involves delegation to the Commission through processes of comitology, which shift the emphasis of decision making towards the output-based conception of legitimacy. The longstanding concern with the 'democratic deficit' in the European Union, reflects debates about the sometimes fragile legitimacy of the European institutions, and attempts to shift the institutional balance which operates between them more towards some input-oriented form of legitimacy. 
The empowerment of the Parliament in the co-decision procedure under the Maastricht Treaty and subsequent reforms under the Amsterdam Treaty were significant steps towards enhancing the democratic input into EC legislation, but the legitimacy of EC decision making has remained quite fragile. Debates about bolstering input-based legitimacy were significant in the deployment of the Convention method used in the development of the European Constitution. This more deliberative form of democracy was seen as an alternative to inter-government decision making on Treaty reform. Unfortunately that method faced and failed an early test in the French and Dutch votes on the Constitutional Treaty. The rejection of the Constitutional Treaty is a salutary lesson in the difficulty of designing governance mechanisms that are perceived to be legitimate.

What impact might the 'new governance' have on the legitimacy of EU activities? We have noted that much of the emphasis of the new governance is in a movement away from governance through law towards processes involving governmental bodies in processes which develop policy and promote compliance with it through the activities of networks which deploy the governance resource of nodality. To the extent that the legitimacy of the EU might be premised upon the observance of the procedural requirements and accountability structures associated with Community method, we might expect this new governance shift to threaten existing understandings of legitimacy. Put simply it appears to threaten the rule of law and associated political and legal accountability mechanisms (Burca and Scott 2006: 5-6). In some domains this threat is addressed through the involvement of a wider range of affected actors, notably in the area of employment policy. But in others, such as economic governance, the risk is of policy making moving to a sphere that is perceived as less transparent and accountable than the use of more traditional methods.

Such an argument assumes that the legitimacy of the EU is substantially premised on the nature of the processes - an inputs-based conception of legitimacy. However, an alternative idea is to suggest, that in contrast to national governmental arrangements, the legitimacy of the EU institutions is much more based on the substance of getting the job done, than on the process. Evaluated against this criterion the emphasis in the new governance on moving away from legal processes, but the retention of governmental actors at the heart of network-based governance processes, 
faces the risk of insufficient expert involvement from civil society organisations. In other words, opportunities for enhancing outcomes through wider diffusion of and exploitation of governing capacity may be missed.

The future agenda of the legitimacy of governance might therefore involve an evaluation of the extent to which non-governmental actors and processes are engaged. In invoking non-governmental activities the question is not just about using the capacities that are there, but also about developing those capacities in a way that supports future governance initiatives. Such capacities are developed not just in isolation, but relationally within the learning processes that are involved in participation in governance. Many instances of such non-governmental activity may not be stimulated by governmental actors, but be merely the subject of observation. We should not expect the legitimation of market or community actors to be wholly or even mainly dependent upon their compliance with the classic mechanisms of accountability which apply to governmental actors. Rather we need to evaluate the extent to which markets and communities offer alternative legitimation mechanisms which might be depended upon. This requires the construction of a more broadly based narrative of legitimacy.

\section{CONCLUSION}

In this paper I suggest that what passes for new in European governance, and in particular the shift from law-based to network-based governance, involving governmental actors, is not terribly innovative. Opportunities to better engage non-governmental capacities appear to be neglected. Equally, where such non-governmental capacity is engaged, sometimes it happens in the limited context of an adapted Community method, as where the drafting of directives is delegated to the social partners, or the enforcement of legal rules is delegated to consumer organisations. Such limited vision might be explicable by reference to the constraints imposed by the quest for legitimacy. The network-based governance model derives some legitimacy from the involvement of EU institutions and domestic governments, which might be threatened if more emphasis were placed on 
non-governmental actors. The limited involvement of non-governmental actors in legal processes is, arguably, legitimated by the knowledge that such actors are constrained by the legal requirements for making and enforcing the law.

And yet, there is good evidence of successful governance processes which operate neither within the immediate framework of EC law, nor with the direct involvement of governmental actors. The leading examples are in the fields of standardisation and self-regulation. These governance regimes use the organisational capacity and treasure of non-governmental actors. In the case of standards, their legitimacy is derived chiefly from the quality of the outputs, and this is tested through the marketing of standards. In the case of advertising self-regulation, such market-testing is an insufficient source of legitimacy, and there has been a constant quest to enhance the involvement of lay people in overseeing the processes so that the protected class, consumers, can have confidence in the regime. Significantly other regimes of Non-State Market Drive Governance (Cashore 2002) have emerged in recent years which testify to the possibility of effective and legitimate supra-national non-state governance regimes. Leading examples includes the Forest Steward Council and the Fair Trade movement, each of which links the pursuit of environmental and social objectives through mechanisms of accreditation, monitoring and labelling, and enables consumers to choose products compliant with the regime in the market-place.

Is the EU doomed by its fragile legitimacy to maintain a limited conception of how governance might be new, or can the insights of regimes which involve a greater role for non-state actors and a wider array of instruments be harnessed to the objectives of EU governance? If the latter is to be achieved, it will require a new narrative of legitimacy which can better accommodate governance beyond law, and governance by nongovernmental actors. 


\section{REFERENCES}

Baggott, Rob, and Larry Harrison. 1986. "The Politics of Self Regulation: The Case For Advertising Control.." Policy and Politics. 14.:145159.

Black, Julia. 2001. "Decentring Regulation: The Role of Regulation and Self-Regulation in a 'Post-Regulatory' World." Current Legal Problems [2001]:103-146.

—. 2005. "What is Regulatory Innovation." in Regulatory Innovation, edited by Julia Black, Martin Lodge, and Mark Thatcher. Cheltenham: Edward Elgar.

Burca, Grainne De, and Joanne Scott. 2006. "Introduction: New Governance, Law and Constitutionalism." Pp. 1-12 in Law and New Governance in the EU and the US, edited by Grainne De Burca and Joanne Scott. Oxford: Hart Publishing.

Cashore, Benjamin. 2002. "Legitimacy and the Privatization of Environmental Governance: How Non-State Market-Driven (NSMD) Governance Systems Gain Rule Making Authority." Governance 15:503-529.

European Commission. 2001. "European Governance: A White Paper."

Geradin, Damien, and Nicolas Petit. 2003. "The Development of Agencies at EU and National Levels: Conceptutal Analysis and Proposals for Reform."

Hallström, Kristine Tamm. 2004. Organizing International Standardization: ISO and IASC in Quest of Authority. Cheltenham: Edward Elgar.

Hodges, Christopher. 2005. European Regulation of Consumer Product Safety. Oxford: Oxford University Press. 
Hodson, Dermot, and Imelda Maher. 2004. "Soft Law and Sanctions: Economic Policy Coordination and Reform of the Stability and Growth Pact'." Journal of European Public Policy 11:798-813.

Hood, Christopher. 1984. The Tools of Government. London: Macmillan.

Kersbergen, Kees Van, and Frans van Waarden. 2004. "'Governance' as a Bridge Between Disciplines: Cross-Disciplinary Inspiration Regarding Shifts in Governance and Problems of Governability, Accountability and Legitimacy." European Journal of Political Research 43:143-171.

Kilpatrick, Claire. 2006. "New EU Employment Governance and Constitutionalism." in Law and New Governance in the EU and the US, edited by Grainne De Burca and Joanne Scott. Oxford: Hart Publishing.

Majone, Giandomenico. 2001. "Regulatory Legtimacy in the United States and the European Union." in The Federal Vision, edited by Kalypso Nicolaidis and Robert Howse. Oxford: Oxford University Press.

Radaelli, Claudio. 2003. "The Open Method of Coordination: A New Architecture for the Governance of the European Union." Stockholm: SIEPS.

Scharpf, Fritz W. 2001. "Democratic Legitimacy Under Conditions of Regulatory Competition." in The Federal Vision, edited by Kalypso Nicolaidis and Robert Howse. Oxford: Oxford University Press.

Schepel, Harm. 2005. The Constitution of Private Governance: Product Standards in the Regulation of Integrating Markets. Oxford: Hart Publishing.

Scott, Colin. 2004. "Regulation in Age of Governance: The Rise of the Post-Regulatory State." Pp. 145-174 in The Politics of Regulation, edited by Jacint Jordana and David Levi-Faur. Cheltenham: Edward Elgar. 
—. 2005. "Agencies for European Governance: A Regimes Approach." in Regulation Through Agencies: A New Paradigm for EC Governance, edited by R. Munoz and N. Petit D. Geradin. Cheltenham: Edward Elgar.

Snyder, Francis. 1993. "The Effectiveness of European Community Law: Institutions, Processes, Tools and Techniques." Modern Law Review 56:19-54. 